\title{
Seasonal budgets of organic matter in the Ubatuba shelf system, SE Brazil. I. Planktonic and benthic components
}

\section{Budgets saisonniers de la matière organique dans l'écosystème côtier d'Ubatuba, au sud-est du Brésil. I. Composantes planctonique et benthique}

\author{
Gecely R.A. Rocha ${ }^{a, *}$, Carmen L.D.B. Rossi-Wongtschowski ${ }^{\text {a }}$, \\ Ana M.S. Pires-Vanin ${ }^{\mathrm{a}}$, Astrid Jarre-Teichmann ${ }^{\mathrm{b}}$ \\ ${ }^{a}$ Instituto Oceanográfico, Universidade de São Paulo, PO Box 9075, 05508-900, São Paulo-SP, Brazil \\ ${ }^{b}$ Danish Institute for Fisheries Research, North Sea Center, PO Box 101, 9850 Hirtshals, Denmark
}

Received 1 June 2002; received in revised form 5 March 2003; accepted 24 March 2003

\begin{abstract}
Planktonic and benthic productivity and consumption were estimated to assess the availability of food to higher trophic-level consumers in the Ubatuba ecosystem on the SE coast of Brazil. The study area included waters from 10 to $100 \mathrm{~m}$ deep and covered $3800 \mathrm{~km}^{2}$. The trophic compartments of the system were established on ecologically or taxonomically related species, considering their relative abundance and similarity of diets and habits. The compartments are phytoplankton, zooplankton, salps, bacterioplankton, cnidaria, polyplacophora, mollusca, carnivorous benthos, detritivorous polychaetes, other detritivorous benthos, penaeidea-caridea, brachyura, and echinodermata. Biomass, production, and consumption were estimated in summer and winter. Plankton biomass, production and consumption were higher in summer than in winter, mainly because of the presence of salps. Primary production was estimated as $1486 \mathrm{~g}_{\text {wet weight m}}^{-2} 3 \mathrm{months}^{-1}$ in summer and $704 \mathrm{~g}$ in winter. Total benthic biomass in summer $\left(101 \mathrm{gww} \mathrm{m}^{-2}\right)$ was twice that in winter $\left(53 \mathrm{gww} \mathrm{m}^{-2}\right)$, but its production and consumption were similar in both seasons.
\end{abstract}

() 2003 Éditions scientifiques et médicales Elsevier SAS and Ifremer/CNRS/IRD. All rights reserved.

\section{Résumé}

Ce travail s'intéresse à la productivité et à la consommation du plancton et du benthos de manière à estimer la disponibilité en nourriture pour les niveaux trophiques supérieurs dans l'écosystème d'Ubatuba, sur la côte sud-est du Brésil. L'aire étudiée couvre une superficie de $3800 \mathrm{~km}^{2}$ sur des fonds allant de $10 \mathrm{~m}$ à $100 \mathrm{~m}$. Les compartiments trophiques sont établis en regroupant des espèces proches sur les plans écologique ou taxinomique, en considérant leur abondance relative et la similarité de leurs habitats et de leur nourriture. Les compartiments sont : phytoplancton, zooplancton, salpes, bactérioplancton, cnidaires, polyplacophores, mollusques, benthos carnivore, polychètes détritivores, autre benthos détritivore, pénéidés-caridés, brachyoures et, enfin, échinodermes. La biomasse, la production, et la consommation sont estimées en hiver et en été. La biomasse, la production et la consommation du plancton sont plus élevées en été surtout en raison de la présence de salpes. La production primaire est estimée à $1486 \mathrm{~g}$ de poids humide par mètre carré pour les trois mois d'été et de $704 \mathrm{~g}$ en hiver. La biomasse benthique totale en été (101 g de poids humide par mètre carré) est deux fois plus élevée qu'en hiver (53), mais sa production et sa consommation sont similaires.

(C) 2003 Éditions scientifiques et médicales Elsevier SAS and Ifremer/CNRS/IRD. All rights reserved.

Keywords: Biomass; Production; Consumption; Subtropical; Western Atlantic

Mots clés : Biomasse ; Production ; Consommation ; Subtropical ; Atlantique Ouest

\footnotetext{
* Corresponding author. Present address: Universidade Estadual de Santa Cruz, Departamento de Ciências Biológicas, Rodovia Ilhéus - Itabuna km 16, 45650-000 Ilhéus BA, Brazil.

E-mail address: gecely@uesc.br (G.R.A. Rocha).
} 


\section{Introduction}

Quantitative assessment of trophic interactions in marine ecosystems has important implications for multi-species fishery management because fish yields are the result of energy flow from primary producers through the aquatic food web. It is therefore important to determine the energy flow available from the lower trophic levels.

Three measures are needed to assess the relative importance of organisms in food webs: biomass, production, and consumption. If the populations are cropped, estimates of withdrawals are also required. Measurements of biomass of individual species can indicate the relative importance of each species in the food web. In order to maintain their biomass, species need to consume energy. Additional consumption is required for production, and part of the production is then available for other, higher-level consumers in the ecosystem. Estimates of the rate of mass flux into and through populations can then be calculated.

Biomass measurements are relatively easy to make in principle, requiring only effective samplers to be employed in a sufficient number over known areas. However, the assessment of production and consumption is time-consuming and expensive work. Because of multi-annual life cycles, interannual variation, and the large amount of time required for sampling at sea, assembling even the basic data for a single species can take more than a decade. Therefore, indirect methods based on body size and other biological parameters have been developed (McNeill and Lawton, 1970; Humphreys, 1979; Banse and Mosher, 1980). These empirical relationships have been widely used (Kalejta and Hockey, 1991; Christensen and Pauly, 1993).

Despite these difficulties, estimates of biomass, production, and consumption of individual species or other taxonomic groups have been obtained by several workers, but few have considered entire assemblages in an ecosystem level (Christensen and Pauly, 1993), especially in tropical and subtropical regions.

Based on these considerations, the objective of our study was to assess punctual information available for the most abundant groups, in order to obtain system estimates of a subtropical continental shelf. In this article, we estimated the amount of food (organic matter) produced and consumed by lower trophic-level organisms (planktonic and benthic). Higher trophic-level consumers (nektonic) are considered in a second article (Rocha et al., 2003, part II).

\section{Material and methods}

Our study area is located on the continental shelf off Ubatuba, which is on south-eastern coast of Brazil. The study area $\left(23^{\circ} 30^{\prime} \mathrm{S}-24^{\circ} 30^{\prime} \mathrm{S}\right.$ and $\left.44^{\circ} 30^{\prime} \mathrm{W}-45^{\circ} 30^{\prime} \mathrm{W}\right)$ included waters from 10 to $100 \mathrm{~m}$ deep Fig. 1 and covered an area of $3800 \mathrm{~km}^{2}$. Three water masses occur in the area: Coastal Water $(\mathrm{CW})$, characterised by high temperature $\left(>25^{\circ} \mathrm{C}\right)$ and low salinity (32-33); Tropical Water (TW) with intermediate

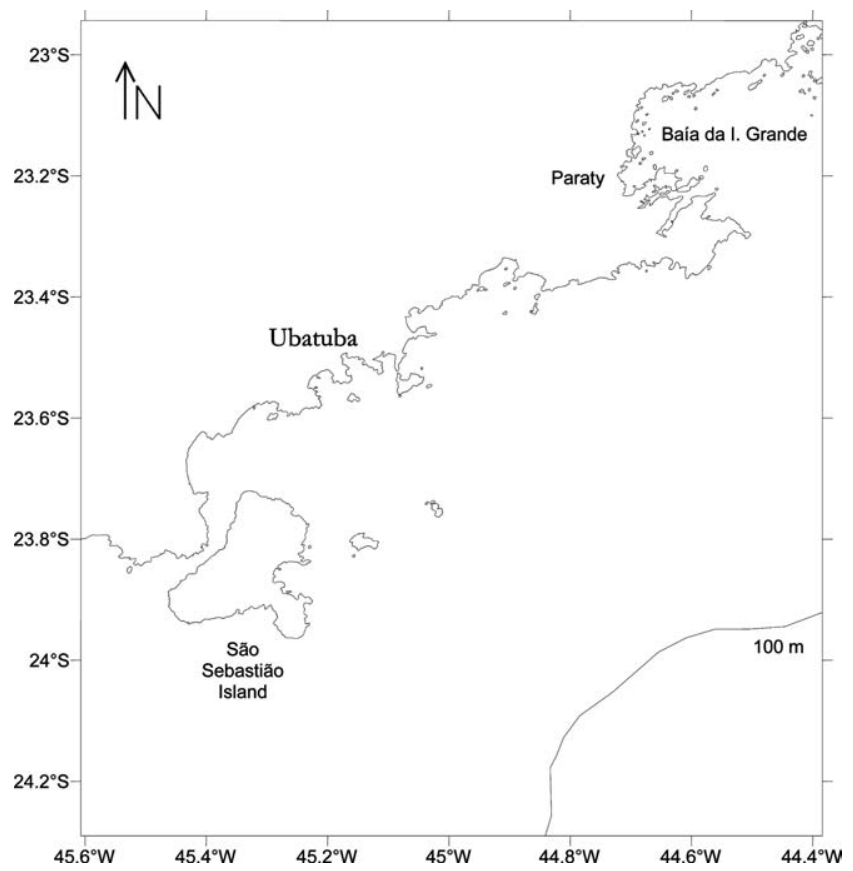

Fig. 1. Study area in the south-eastern Brazilian shelf.

temperature $\left(20-23{ }^{\circ} \mathrm{C}\right.$ ) and high salinity (about 36); and South Atlantic Central Water (SACW) with low temperature $\left(16-18^{\circ} \mathrm{C}\right)$ and high salinity (35-36). During the summer, nutrient-rich SACW moves onshore and is often found in the central and outer portions of the continental shelf (20$100 \mathrm{~m}$ ), while $\mathrm{CW}$ is found along a narrow band inshore. These water movements result in a vertical stratification over the inner shelf, with a strong thermocline at middle depths. In winter, when SACW is restricted to the outer shelf, horizontal and vertical thermal gradients are reduced and almost no stratification is observed on the inner shelf (Castro-Filho et al., 1987).

The trophic compartments of the system are based on ecologically and taxonomically related species, considering information of their relative abundance and similarity of diets and habits, reported by Pires-Vanin (1993). Considering the seasonal water mass dynamics, we decided to estimate biomass, production, and consumption for each compartment in summer and winter. Wet weight $\left(\mathrm{g} \mathrm{m}^{-2}\right)$ was used as the unit of standing stock, and a three-monthly period as the unit of time.

The four compartments of plankton were: phytoplankton, bacterioplankton, zooplankton, and salps (present only in summer). The benthic subsystem was divided into brachyura, cnidaria, other carnivorous benthos, detritivorous polychaetes, mollusca (detritivorous gastropoda and bivalvia), polyplacophora (present only in summer), penaeidea-caridea, echinodermata, and other detritivorous benthos (several taxonomic groups, feeding on dissolved and particulate organic matter). Taxonomic composition of these compartments is reported in Table 1 .

As information from direct measurements from the Ubatuba area were not available for each compartment, em- 
Table 1

Biomass $(B)$, production per biomass (P/B) according to Table 3, and production for benthic compartments in summer and winter

\begin{tabular}{|c|c|c|c|c|c|c|}
\hline & \multicolumn{3}{|l|}{ Summer } & \multicolumn{3}{|l|}{ Winter } \\
\hline & $B\left(\mathrm{~g} \mathrm{~m}^{-2}\right)$ & $\mathrm{P} / \mathrm{B}\left(\right.$ year $\left.^{-1}\right)$ & $\begin{array}{l}\text { Production } \\
3 \text { months }\end{array}$ & $B\left(\mathrm{~g} \mathrm{~m}^{-2}\right)$ & P/B $\left(\right.$ year $\left.^{-1}\right)$ & $\begin{array}{l}\text { Production } \\
3 \text { months } \\
\end{array}$ \\
\hline Brachyura & 20.50 & 0.6 & 3.04 & 0.46 & 0.6 & 0.07 \\
\hline Cnidaria & 11.06 & $1.0^{\mathrm{a}}$ & 2.76 & 0.53 & $1.0^{\mathrm{a}}$ & 0.13 \\
\hline Other carnivorous benthos & 5.07 & & 5.00 & 11.19 & & 10.55 \\
\hline Asteroidea & 0.02 & 0.5 & 0.00 & 0.02 & 0.6 & 0.00 \\
\hline Gastropoda & 0.99 & 6.6 & 1.63 & 0.94 & 5.2 & 1.23 \\
\hline Polychaeta & 3.85 & 3.5 & 3.37 & 10.13 & 3.7 & 9.32 \\
\hline Scaphopoda & 0.18 & & & 0.09 & & \\
\hline Stomatopoda & 0.02 & & & 0.01 & & \\
\hline Detritivorous polychaeta & 9.28 & 2.9 & 6.80 & 9.77 & 3.1 & 7.54 \\
\hline Mollusca & 7.76 & & 4.96 & 12.44 & & 6.38 \\
\hline Bivalvia & 6.78 & 2.1 & 3.59 & 11.50 & 1.9 & 5.35 \\
\hline Gastropoda & 0.99 & 5.5 & 1.37 & 0.94 & 4.4 & 1.03 \\
\hline Polyplacophora & 24.33 & $0.4^{\mathrm{a}}$ & 2.56 & & & \\
\hline Penaeidea-caridea & 0.10 & & 0.06 & 0.27 & & 0.21 \\
\hline Caridea & 0.04 & 4.5 & 0.05 & 0.08 & 7.5 & 0.15 \\
\hline Penaeidea & 0.06 & 0.9 & 0.01 & 0.19 & 1.2 & 0.06 \\
\hline Echinodermata & 18.54 & & 5.16 & 12.71 & & 4.78 \\
\hline Crinoidea & 0.00 & 0.4 & 0.00 & 1.01 & 0.5 & 0.13 \\
\hline Echinoidea & 0.01 & 0.5 & 0.00 & 0.05 & 0.7 & 0.01 \\
\hline Holothuroidea & 0.01 & 5.6 & 0.02 & 0.00 & 6.9 & 0.01 \\
\hline Other detritivorous benthos & 4.75 & & 4.20 & 5.77 & & 2.59 \\
\hline Amphipoda & 0.92 & 6.9 & 1.59 & 0.23 & 11.7 & 0.67 \\
\hline Chelicerata & & & & 1.83 & & \\
\hline Cirripedia & 0.22 & & & 0.01 & & \\
\hline Copepoda & 0.01 & 12.0 & 0.03 & 0.00 & 16.4 & 0.02 \\
\hline Cumacea & 0.33 & 8.9 & 0.74 & 0.04 & 16.4 & 0.16 \\
\hline Isopoda & 0.34 & 7.7 & 0.65 & 0.01 & 19.8 & 0.07 \\
\hline Leptostraca & 0.07 & & & 0.00 & & \\
\hline Nematoda & & & & 0.74 & $9.0^{\mathrm{a}}$ & 1.67 \\
\hline Nemertinea & 0.42 & & & & & \\
\hline Ostracoda & 0.02 & & & 0.03 & & \\
\hline Priapulida & & & & 0.85 & & \\
\hline Sipuncula & 0.23 & & & 1.97 & & \\
\hline Tanaidacea & 0.10 & & & 0.05 & & \\
\hline Tunicata & 2.09 & $2.3^{\mathrm{a}}$ & 1.20 & & & \\
\hline
\end{tabular}

${ }^{a}$ Cited by Opitz (1991).

pirical relationships and literature values from other shelf systems were considered. The equations were chosen based on the availability of the parameters we had studied.

\subsection{Estimates of biomass}

Biomass values were available for most of the compartments (Pires-Vanin, 1993). However, some of these values have to be transformed to wet weight, as reported in Table 2 We considered $0.06 \mathrm{~g} \mathrm{C}=1 \mathrm{~g}$ wet weight (Valiela, 1995).
Bacterial biomass was calculated from cell numbers estimated in Ubatuba (Pires-Vanin, 1993), using the expression proposed by Linley et al. (1981):

$$
\text { Wet weight }=\mathrm{N} \cdot \mathrm{V} \cdot \mathrm{SG} \cdot 10^{-6} \mathrm{mg} \mathrm{l}^{-1}
$$

where $N$ is the number of cells $\left(10^{6} \mathrm{ml}^{-1}\right) ; V$ is the mean volume of the cells $\left(\mu \mathrm{m}^{3}\right)$; SG is the specific gravity of the cells. A volume of $0.06 \mu \mathrm{m}^{3}$, and a specific gravity of 1.1 were used Table 2, 
Table 2

Estimates of biomass and production of phytoplankton, bacterioplankton, zooplankton, and salps during summer and winter, with annual values. All local data were reported in Pires-Vanin (1993)

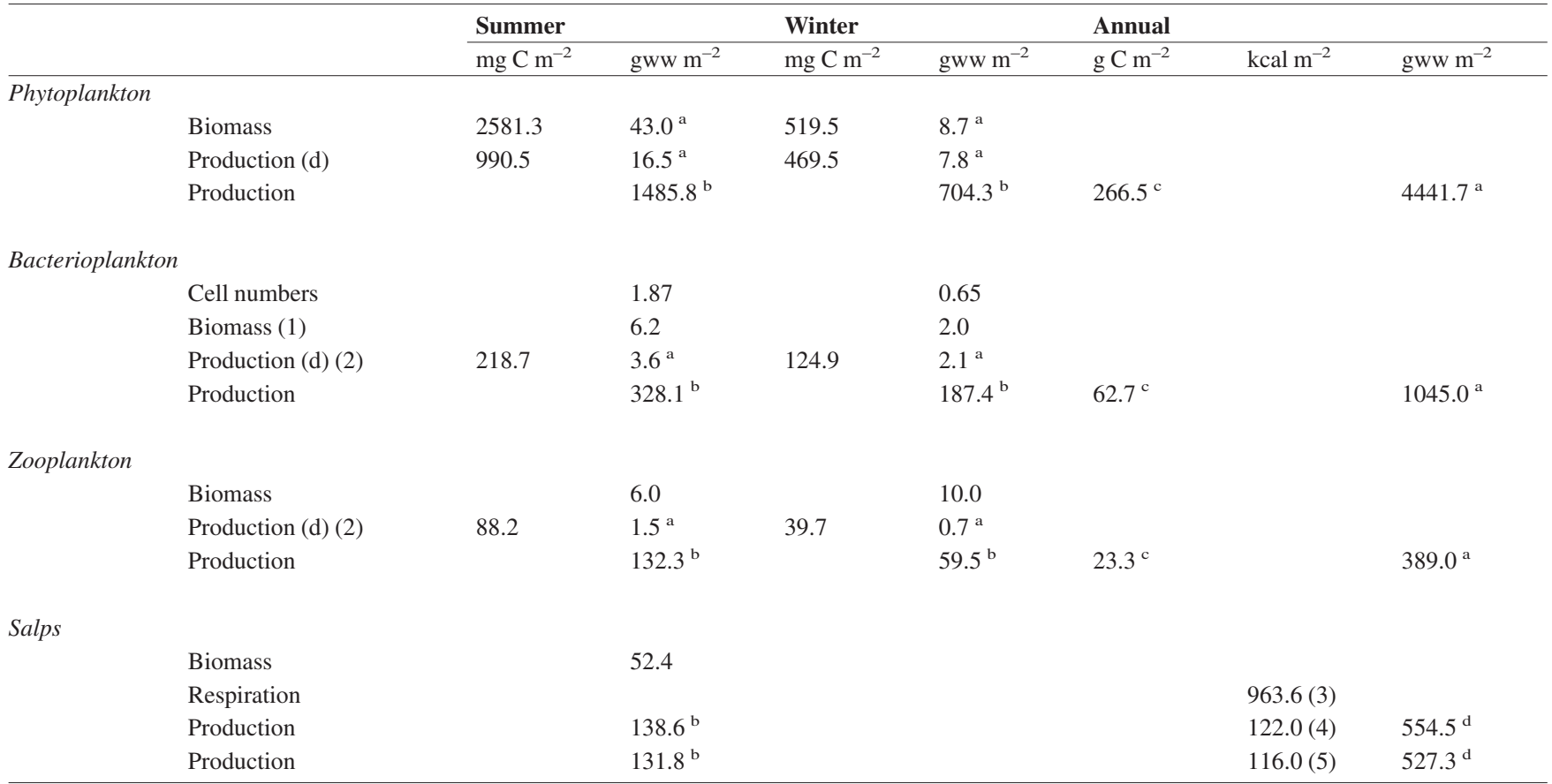

(1) Using the empirical relation from Linley et al. (1981). (2) Using the empirical relation from Cole et al. (1988). (3) Value converted from Ikeda (1970). (4) Using the empirical relation from McNeill and Lawton (1970). (5) Using the empirical relation from Humphreys (1979).

${ }^{\mathrm{a}} 0.06 \mathrm{~g} \mathrm{C}=1 \mathrm{~g}$ wet weight (Valiela, 1995).

b Three months.

c Summer plus winter multiplied by 2 .

d $0.22 \mathrm{kcal}$ per gram wet weight for tunicates (Thayer et al., 1973).

The volume of salps measured by flow-meters off Ubatuba was $437 \mathrm{ml} \mathrm{m}^{-2}$. For most plankton samples, weight and volume are readily convertible: $1 \mathrm{ml}$ of plankton weighs approximately $1 \mathrm{~g}$. However, some studies indicated that it is not valid for samples containing large numbers of salps. In this case, wet plankton volume overestimates the volume occupied by the organisms (Ahlstrom and Thrailkill, 1963). Based on their study, the volume of salps was reduced by $80 \%$ (shrinkage) and then corrected for interstitial water value by subtracting $40 \%$ of this value.

Benthic biomass was obtained using both trawl and grab values. Sampling techniques were described by Pires-Vanin (1993). Values for each compartment are reported in Table 1

\subsection{Estimates of production}

Data of phytoplankton primary production off Ubatuba in summer and winter (Pires-Vanin, 1993) were converted to wet weight as reported in Table 2

As no data of production of bacteria were available for Ubatuba shelf, we used a regression between primary production (PP) and bacterial production (BP), established by Cole et al. (1988):

$$
\log \mathrm{BP}=0.75 \log \mathrm{PP}+0.093 \mathrm{mg} \mathrm{C} \mathrm{m}^{-2} \mathrm{day}^{-1}
$$

Daily values were summed to get 3-month periods (summer and winter), as reported in Table 2.
A relationship between zooplankton production $(\mathrm{ZP})$ and primary production (PP) proposed by Cole et al. (1988) was also used:

$$
\log \mathrm{ZP}=1.07 \log \mathrm{PP}-1.26 \mathrm{mg} \mathrm{C} \mathrm{m}^{-2} \text { day }^{-1}
$$

Daily values were summed to get 3-month periods (summer and winter), as reported in Table 2

The annual production of salps was estimated based on respiration rates, according to empirical equations proposed by McNeill and Lawton (1970) and Humphreys (1979), respectively:

$$
\begin{aligned}
& \log \mathrm{P}=0.8262 \log \mathrm{R}-0.0948 \\
& \log \mathrm{P}=0.971 \log \mathrm{R}-0.500
\end{aligned}
$$

in $\mathrm{kcal} \mathrm{m}^{-2}$ year $^{-1}$. As salp respiration values were not available for the Ubatuba area, an average value of $0.28 \mu \mathrm{l}$ mgww $^{-1} \mathrm{~h}^{-1}$, obtained from values cited for T. democratica by Ikeda (1970), was used to estimate annual respiration. We transformed the value in $\mu$ to kcal considering $1 \mathrm{l} \mathrm{O}_{2}$ consumed $=5 \mathrm{kcal}$ (Valiela, 1995), and the production value obtained in kcal to grams of wet weight using a caloric content of $0.22 \mathrm{kcal} \mathrm{gww}^{-1}$ for tunicates (cited by Thayer et al., 1973). Production of the benthic compartments was estimated from their P/B values, calculated using the empirical relationship proposed by Brey (1999): 
Table 3

Dummies $(D)$, wet weight (ww), mass $(M)$, depth $(d)$ and temperature $(T)$ used for estimating production per biomass $\left(\mathrm{P} / \mathrm{B}\right.$, year $\left.{ }^{-1}\right)$ for benthic groups in summer and winter, according to the empirical relation from Brey (1999). $D=$ dummy, $\mathrm{LM}=$ motile epifauna, $\mathrm{FC}=$ food carnivore, $\mathrm{T}=$ taxon, $\mathrm{M}=$ mollusca, $\mathrm{C}=$ crustacea, $\mathrm{P}=$ polychaeta, $\mathrm{E}=$ echinodermata, $\mathrm{BL}=$ biotope lake. $\log \mathrm{P} / \mathrm{B}=10.154-0.271 \log M-2824.247 \mathrm{TK}-1-0.063 \log (d+1)+0.13 \mathrm{DLM}+0.076 \mathrm{DFC}$ $-0.311 \mathrm{DTM}-0.154 \mathrm{DTC}-0.266 \mathrm{DTP}-0.472 \mathrm{DTE}-0.150 \mathrm{DBL}$

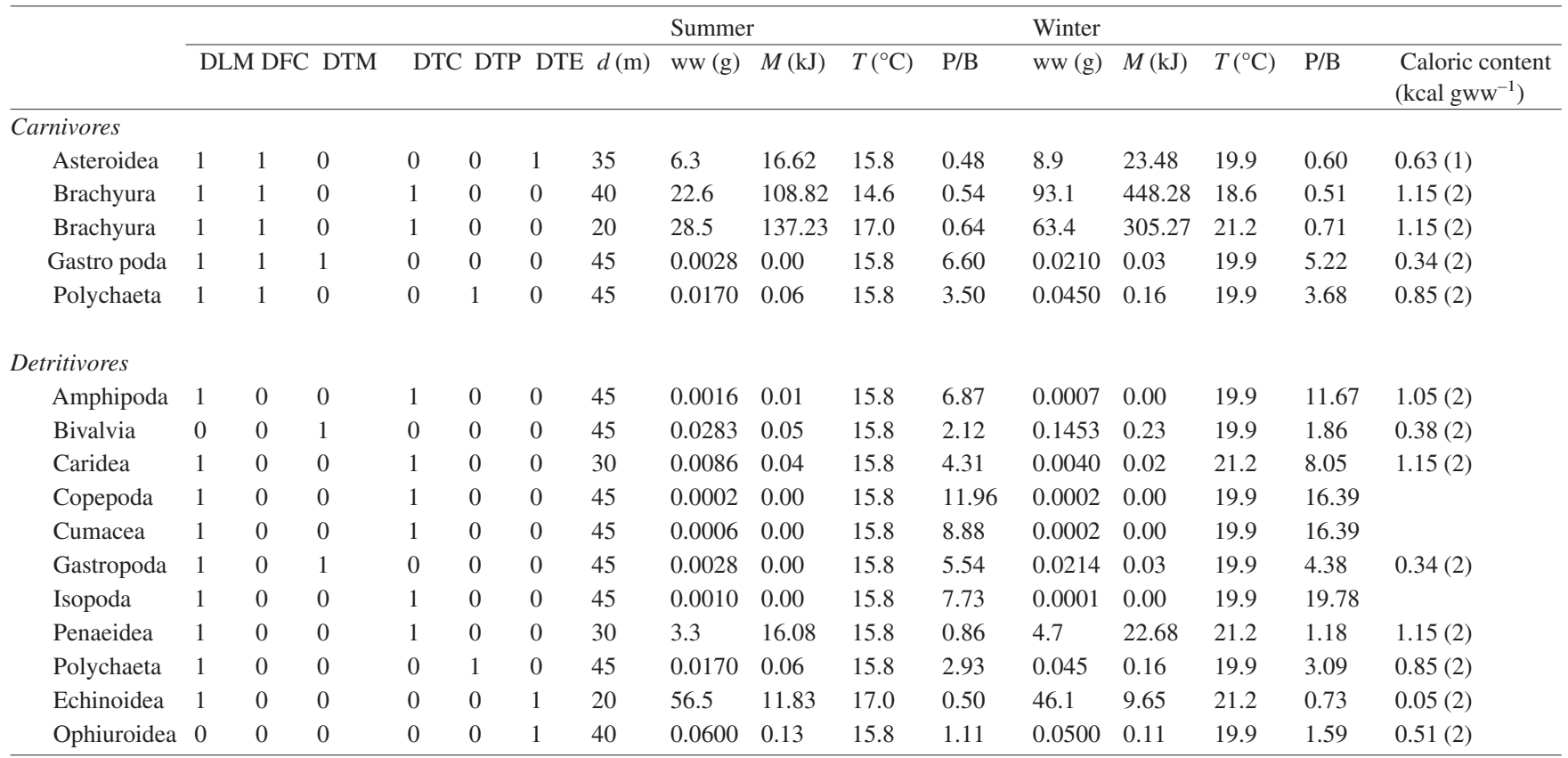

(1) Brawn et al. (1968). (2) Thayer et al. (1973).

$1 \mathrm{kcal}=4.187 \mathrm{~kJ}$

$\log \mathrm{P} / \mathrm{B}=10.154-0.271 \log \mathrm{M}-2824.247 \mathrm{TK}^{-1}-$

$0.063 \log (\mathrm{D}+1)+0.13 \mathrm{DLM}$

$+0.076 \mathrm{DFC}-0.311 \mathrm{DTM}-0.154$ DTC -

$$
0.266 \text { DTP - 0.472 DTE - 0.150 DBL }
$$

where $\mathrm{P} / \mathrm{B}$ is production per biomass $\left(\mathrm{year}^{-1}\right), M$ is mean individual body mass $(\mathrm{kJ})$, TK is temperature in $\mathrm{K}\left(=T^{\circ} \mathrm{C}+\right.$ 273.1), $D$ is depth (m), DLM is dummy motile epifauna, DFC is dummy food carnivore, DTM is dummy taxon mollusca, DTC is dummy taxon crustacea, DTP is dummy taxon polychaeta, DTE is dummy taxon echinodermata and DBL is dummy biotope lake. "Dummy" variable equals 1 if the condition is fulfilled and equals 0 , otherwise.The $\mathrm{P} / \mathrm{B}$ ratios obtained are reported in Table 3 Brawn et al. (1968) and Thayer et al. (1973) give caloric content values (kcal per gram of wet weight), converted according to a factor of $1 \mathrm{kcal}$ $=4.187 \mathrm{~kJ}$ (Christensen and Pauly, 1993). Because of the lack of $\mathrm{P} / \mathrm{B}$ estimates for cnidaria and polyplacophora, data cited by Opitz (1991) were used.These ratios were then used to calculate the values of production in summer and winter, as reported in Table 1 .

\subsection{Estimates of consumption}

All the consumption estimates were based on gross efficiency ratios (production per consumption). A value of 0.50 was used for bacterioplankton and of 0.25 for zooplankton (Valiela, 1995). For salps, an hourly consumption of $2.5 \%$ of body carbon (Deibel, 1982) converted to percent wet weight was used.
For the benthic groups, we used gross efficiencies of 0.09 for herbivores and 0.30 for carnivores, following the empirical relationship found by Brey (1999). An intermediate value of 0.15 was assumed for omnivores.

\section{Results and discussion}

The estimates of biomass, production and consumption of each compartment in summer and winter are reported in Table 4. Plankton biomass, production, and consumption were higher in summer than in winter, mainly because of the presence of salps. Benthic biomass was twice as high in summer as in winter. Nevertheless, production and consumption were similar in both seasons. Values for detritivores in the benthos were always higher than those for the carnivores.

During the summer, planktonic groups accounted for $46 \%$ of the biomass, $96.6 \%$ of the production, and $76 \%$ of the consumption. Benthic groups accounted for $48 \%$ of the biomass, represented only $3.0 \%$ of the production, but made up to $22.7 \%$ of the consumption. Fish and squids contributed little to the system, accounting for $6 \%$ of the biomass and less than $2 \%$ of the production and consumption. In winter, planktonic groups, mainly the zooplankton, were relatively less abundant (23\%) and consumed less $(57 \%)$, because of the absence of salps. Benthic biomass (66\%) and consumption $(41 \%)$ increased because of the contribution of the detritivorous groups. Nektonic biomass (11\%), detailed in Rocha et al. (2003) (part II), was also higher in this season.

Light regime and supply of dissolved inorganic nutrients are important factors in regulating the magnitude of primary 
Table 4

Biomass $\left(B, \mathrm{~g} \mathrm{~m}^{-2}\right)$, production $\left(P, \mathrm{~g} \mathrm{~m}^{-2} 3\right.$ months $\left.^{-1}\right)$ and consumption $\left(Q, \mathrm{~g} \mathrm{~m}^{-2} 3\right.$ months $\left.^{-1}\right)$ for planktonic and benthic compartments in summer and winter

\begin{tabular}{|c|c|c|c|c|c|c|c|}
\hline & & \multicolumn{3}{|c|}{ Summer } & \multicolumn{3}{|c|}{ Winter } \\
\hline & & B & $\mathrm{P}$ & Q & $\mathrm{B}$ & $\mathrm{P}$ & Q \\
\hline \multicolumn{8}{|l|}{ Plankton } \\
\hline & Phytoplankton & 43.0 & 1485.8 & & 8.7 & 704.3 & \\
\hline & Bacterioplankton & 6.2 & 328.1 & 656.2 & 2.0 & 187.4 & 374.8 \\
\hline & Zooplankton & 6.0 & 132.3 & 529.2 & 10.0 & 59.5 & 238.0 \\
\hline & Salps & 52.4 & 138.6 & 933.4 & & & \\
\hline
\end{tabular}

Benthos

Carnivores

Brachyura

Cnidaria

Other carnivorous benthos

$\begin{array}{ll}20.5 & 3.0 \\ 11.0 & 2.8 \\ 5.0 & 5.0\end{array}$

5.0

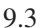

7.8

24.3

0.1

18.5

4.7

209
3.0
2.8

5.0

$\begin{array}{ll}9.3 & 6.8 \\ .8 & 5.0 \\ 4.3 & 2.6 \\ .1 & 0.1 \\ 8.5 & 5.2 \\ .7 & 4.2\end{array}$

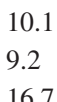

16.7
0.5
0.5

11.2

\section{1}

0.1

10.5
0.2

0.4

35.2

Detritivorous polychaeta
Mollusca
Polyplacophora
Penaeidea + caridea
Echinodermata
Other detritivorous benthos

Total

6.8
5.0
2.6
0.1
5.2
4.2

2119

$\begin{array}{llll}75.5 & 9.8 & 7.5 & 83.8 \\ 55.1 & 12.4 & 6.4 & 70.9 \\ 17.1 & & & \\ 0.4 & 0.3 & 0.2 & 1.4 \\ 57.3 & 12.7 & 4.8 & 53.1 \\ 46.7 & 5.8 & 2.6 & 28.8 \\ & & & \\ 2407 & 74 & 983 & 887\end{array}$

production in marine ecosystems. Both might be limiting factors, the former in temperate regions, the second in the tropics and subtropical regions (Smetacek, 1984).

In summer, the dominant influence on productivity of the Ubatuba system is associated with the presence of the South Atlantic Central Water (SACW) that transports cold, nutrient-rich water onto the shelf (Pires-Vanin, 1993). Transient blooms of phytoflagellates, diatoms, and other organisms indicate the importance of the new production. However, the inshore ratio between new and regenerated production $(f)$ was estimated for this system as only 0.05 (subsurface) and 0.10 (bottom) with episodic enrichment increases up to 0.26 (Metzler et al., 1997). Higher inputs of suspended matter, sediment, and organic matter of continental origin, observed during the rainy season (summer), are some of the other factors that contribute to increase the productivity off Ubatuba in this season (Mahiques, 1995).

Nevertheless, even with this large input of nutrients, the primary production is not high. The Ubatuba value (266 g C $\mathrm{m}^{-2}$ year $^{-1}$ ) is higher than that from the southern Brazilian shelf $\left(160 \mathrm{~g} \mathrm{C} \mathrm{m}^{-2}\right.$ year $\left.^{-1}\right)$ reported by Odebrecht and Garcia (1997), and from some other systems (Christensen and Pauly, 1993). However, other systems are more productive. For example, in the Gulf Stream off the Georgia Bight, a tropical shelf ecosystem, Deibel (1985) reported values ranging from 2 to $6 \mathrm{~g} \mathrm{C} \mathrm{m}^{-2} \mathrm{~d}^{-1}$, much higher than the summer values we observed in Ubatuba $\left(1 \mathrm{~g} \mathrm{C} \mathrm{m}^{-2} \mathrm{~d}^{-1}\right)$. An average daily production of $2 \mathrm{~g} \mathrm{C} \mathrm{m}^{-2} \mathrm{~d}^{-1}$ or more is observed in the Peruvian and Benguela upwelling systems (Mendo et al., 1989; Brown et al., 1991).

In order to estimate global primary production, Longhurst et al. (1995) divided the oceans into four primary domains and 57 biogeochemical provinces. The annual value for Ubatuba (266 $\mathrm{g} \mathrm{C} \mathrm{m}^{-2}$ year $^{-1}$ ) was similar to that estimated for the Brazilian province (302 $\mathrm{g} \mathrm{C} \mathrm{m}^{-} 2$ year $^{-1}$ ), but lower than the "coastal domain" and upwelling provinces ( 400 g $\mathrm{C} \mathrm{m}^{-2}$ year $^{-1}$ ), systems with the highest values estimated by Longhurst et al. (1995).

Organic matter released during grazing, as well as sinking dead phytoplankton and zooplankton, may be used by heterotrophic organisms, including bacteria (Cole et al., 1988). Sporadic events of high chlorophyll-a density and intense herbivory, such as blooms of phytoplankton and salps, constitute important sources of organic matter. In Ubatuba, the higher amount of bacteria in summer might be associated with these events, while phytoplankton senescence might be responsible for the relative increase of detritus-attached bacteria in winter (Pires-Vanin, 1993).

The relationship proposed by Cole et al. (1988), used to estimate bacterial production in the Ubatuba system, resulted in mean values near to those cited by Valiela (1995) for tropical regions. However, these were moderate values, resulting from a low primary production, as already discussed.

For warm-water zooplankton species, estimates of daily $\mathrm{P} / \mathrm{B}$ have converged on values between 0.25 and 0.50 (Shushkina et al., 1978; Longhurst and Pauly, 1987). However, total zooplankton production has rarely been estimated. In the inland Sea of Japan, copepod production values of 46 and 34 $\mathrm{g} \mathrm{C} \mathrm{m}^{-2}$ year $^{-1}$ were, respectively, reported by Koga (1986) and Uye et al. (1987). In a diagram of energy flow for a plankton community in a Peruvian upwelling zone, values of 0.98 and $0.19 \mathrm{kcal} \mathrm{m}^{-2} \mathrm{~d}^{-1}$ were shown for non-predatory and predatory zooplankton, respectively (Shushkina et al., 1978). However, the reported values were variable and much higher 
values might be obtained in that and other equatorial systems (Vinogradov et al., 1976; Le Borgne, 1982).

Salps can sometimes be an important constituent of zooplankton. Salp blooms, reaching extremely high concentrations and covering thousands of square kilometres, have been observed in many coastal systems (Deibel, 1985; Paffenhöfer and Lee, 1987; Ménard et al., 1994). Actual measures of standing crop are crucial for constructing realistic budgets, but accurate determination of the biomass of salps might be difficult. For most plankton samples, weight and volume are readily convertible: $1 \mathrm{ml}$ of plankton weighs approximately $1 \mathrm{~g}$. Salps and total zooplankton, however, differ in proportion of volume to weight. While zooplankton has a relationship of dry weight $=15 \%$ wet weight and carbon weight $=$ $45 \%$ dry weight (Ikeda, 1970), the corresponding relationships for salps are 2-4\% (of displacement volume) (Riley and Gorgy, 1948; Tranter, 1960) and 5-8\% (Harbison and Gilmer, 1976; Le Borgne, 1982). Therefore, zooplankton samples with different species composition will have different volume/biomass relationships (Ahlstrom and Thrailkill, 1963). This is a problem in constructing organic matter budgets. In most of the studies, zooplankton (and salps) measures are obtained as volumetric values, which must be converted to biomass.

Moreover, the original live volume of plankton decreases with time of preservation. The amount of decrease is related to the composition, being greatest for samples in which salps are dominant (Ahlstrom and Thrailkill, 1963). If the determination is made before preservation or within the first few days of collection, the percentage composition and the biomass could be much higher. Assessment of the biomass of gelatinous zooplankton is particularly difficult because these organisms are fragile and patchy in distribution. Therefore, it is not surprising that gelatinous zooplankton has been rarely incorporated into ecosystem models, because reliable data on their abundance and biomass are limited (Alldredge, 1984). Very few budget studies take salps into consideration (Michaels and Silver, 1988).

The small phytoplankton biomass observed off Ubatuba in summer might be a result of predation by salps, whose numbers were high. These organisms have high filtration rates (Deibel, 1982; Andersen, 1985). The wide size range of particles consumed by salps may reduce the concentration of food available both for juvenile and adult copepods (Deibel, 1985), which could be a reason for the low zooplankton abundance observed in Ubatuba in summer.

There are very few estimates of $\mathrm{P} / \mathrm{B}$ or production of salps. In the Seto Inland Sea (Japan), Koga (1986) reported a production of $47 \mathrm{~g} \mathrm{C} \mathrm{m}^{-2}$ year $^{-1}$ and a $\mathrm{P} / \mathrm{B}$ ratio equal to 67 year $^{-1}$. Le Borgne (1982) estimated a daily P/B of 1.52 for Salpa fusiformes. We have not used this value in our budget because it seems unrealistically high, comparable to the P/B ratios of bacteria and other unicellular organisms (Valiela, 1995). Growth rate, turnover time, and intrinsic rate of natural increase can be considered as measures of the potential productivity of a population. Although salps show very high values for all these parameters (Heron, 1972), they are not as high as the values reported for ciliates or bacteria (Fenchel, 1974).

In this study, the production of salps was estimated from their oxygen consumption (after Ikeda, 1970). Low respiration values have been frequently reported for medusoid and gelatinous organisms (Ikeda, 1970; Biggs, 1977). If salps and zooplankton have a similar production/respiration relationship, we could expect a lower P/B for salps than for zooplankton. Another comparison is between thaliaceans and ctenophorans, which have similar respiration rates (Biggs, 1977) and maximum growth rates (Alldredge, 1984). The value of production estimated here for salps is in the range of 0.02 and $0.12 \mathrm{~d}^{-1}$ cited for Ctenophora in Alldredge (1984). It seems most probable that the productivity of salps is high at the beginning of a bloom, close to the value estimated by Le Borgne (1982), then decreasing rapidly, leading to a moderate annual value. $\mathrm{P} / \mathrm{B}$ ratios cannot be higher than hourly Q/Bs varying from $2.5 \%$ to $8.0 \%$ reported by Deibel (1982) and Andersen (1985). Undoubtedly, long and sequential studies are still needed.

Pelagic bacteria are favoured by the increase of organic matter released during grazing by salps, as well as sediment bacteria and benthic organisms, through a rapid sinking of their faecal pellets. This might be the major form of input to the benthos in summer, whereas in winter the contribution of phytoplankton to benthic food supply increases. In some coastal areas, factors such as high sedimentation rates, resuspension, terrestrial input, and input from macroalgal or kelp beds have been reported as relevant for the benthic food supply (Smetacek, 1984). A C/N ratio study on the origin of the sedimentary organic matter in some bays off Ubatuba showed areas with a predominance of terrestrial contribution and other areas with the main input from pelagic sources (Mahiques, 1995). The continental input is said to be strongly associated with rainfall, and is more important in summer, while re-suspension is higher in winter, because of a higher frequency of cold fronts (Mahiques, 1995).

Many estimates have been made on the production of individual benthic species and small taxonomic groups, but few studies have considered entire benthic assemblages (Baird and Milne, 1981; Kalejta and Hockey, 1991). Furthermore, most estimates of production have been made for shallow areas, such as estuaries and beaches, in temperate regions (Warwick et al., 1978), and few data are available on the production of benthic faunas on continental shelves (Buchanan and Warwick, 1974), especially in tropical and subtropical regions (Longhurst and Pauly, 1987). Species and group P/B rates calculated for the Ubatuba shelf were in the range reported in the literature (Valiela, 1995). However, for the total macrofauna, considering crustaceans, polychaetes, and molluscs, the P/B ratio was higher $\left(3.4\right.$ year $\left.^{-1}\right)$ than those cited in several studies from temperate regions (Baird and Milne, 1981; Warwick et al., 1978). Kalejta and Hockey (1991) reviewed studies of macrobenthic communities on intertidal mudflats and realised that $\mathrm{P} / \mathrm{B}$ values were consis- 
tently lower than 2 from areas north of $40^{\circ} \mathrm{N}$. For estuaries between $30^{\circ} \mathrm{N}$ and $40^{\circ} \mathrm{N}$ of latitude, $\mathrm{P} / \mathrm{B}$ rates varied from 3 to 5 , near the values from Ubatuba.

Because production data from tropical benthic communities are rare, Longhurst and Pauly (1987) suggested using data on benthic community P/B from comparable studies in temperate regions, such as those of Warwick et al. (1978), multiplied by a factor of 2 or 3 . The range of $\mathrm{P} / \mathrm{B}$ values suggested by Longhurst and Pauly (1987) would vary from 1.2 to 3.8 year $^{-1}$ depending on the kind of sediment. The benthic $\mathrm{P} / \mathrm{B}$ estimated for Ubatuba is within this range of values.

For estuaries, Kalejta and Hockey (1991) found a positive relationship between production of invertebrates and mean annual ambient temperature. Based on their graph, a production of more than $80 \mathrm{~g}$ dry weight $\mathrm{m}^{-2}$ year ${ }^{-1}$ would be expected for Ubatuba (average temperature $20^{\circ} \mathrm{C}$ ). Nevertheless, the annual production of crustaceans, polychaetes, and molluscs in Ubatuba was estimated as equal to $170 \mathrm{~g}$ of wet weight (=33 gdw), a lower value than was expected. Apparently, due to the lack of data from tropical regions, the curve established by Kalejta and Hockey (1991) may overestimate the production from tropical regions. On the other hand, much higher production values have been recorded for invertebrates in temperate estuaries, and bays (Baird and Milne, 1981; Wulff and Ulanowicz, 1989) than for marine benthos (Buchanan and Warwick, 1974; Warwick et al., 1978). According to those data, estuarine benthic communities seem to be more productive than marine communities. In any event, more studies of invertebrate productivity in tropical and subtropical ecosystems are required to determine more precisely the relationship between production and latitude.

Increases in $\mathrm{P} / \mathrm{B}$ ratios from temperate to tropical regions have long been recognised (Longhurst and Pauly, 1987; Kalejta and Hockey, 1991). It is also widely known that depth and temperature are important factors in determining the magnitude of secondary production, but their importance for productivity has rarely been quantified. Many studies have estimated benthic invertebrate production according to the equation of Banse and Mosher (1980), based only on body mass. Brey (1999) established an empirical regression for estimating $\mathrm{P} / \mathrm{B}$ rates that take into account body mass, temperature, and depth, besides taxonomic domains. Brey et al. (1996) performed a test between two methods of estimating $\mathrm{P} / \mathrm{B}$ from empirical data and $\mathrm{P} / \mathrm{B}$ values computed by the increment summation method. They concluded that the accuracy of both approaches was low at the population level, but both of them may be useful in investigations on community energetic. Further comparisons between empirical estimates and direct methods are required in order to obtain more realistic $\mathrm{P} / \mathrm{B}$ values.

Studies on assemblage production are rare, but there are no consumption studies at this level. The only information available refers to individual consumption in the laboratory; there is none on field populations or communities. Therefore, it was not possible to compare our values with other ecosystems.

Biomass values were close to other tropical shelf systems, such as those in Mexico and Venezuela (Christensen and Pauly, 1993). Production in summer was equal to $2119 \mathrm{~g}$ wet weight $\mathrm{m}^{-2} 3$ months $^{-1}$, being 1486 from primary production, and 633 from secondary production. In winter, a total of $983 \mathrm{~g}$ wet weight $\mathrm{m}^{-2} 3$ months $^{-1}$ was available, being 704 from primary production, and 279 from secondary production. These values are also close to other continental shelf systems, but lower than those observed in estuaries, and coral reefs (Wulff and Ulanowicz, 1989; Opitz, 1991; Christensen and Pauly, 1993).

Changing environmental conditions were an important contributing factor underlying the observed trends in the organic matter flow in this system. Total biomass, production, and consumption of Ubatuba continental shelf system were twice as high in summer as in winter. Seasonal differences in availability of food resources from the lower trophic levels are one of the factors that determine fish biomass or fish yields of the system (Rocha et al., 2003, part II).

Our results suggest that Ubatuba is a pelagic-dominated system during the summer, which, due to the impact of frontal processes, bears some characteristics of upwelling systems. Nonetheless, the importance of detritus on this system is much higher than in upwelling ones, as can be seen in the detritivorous biomass.

It is important to investigate the long-term temporal scale of community dynamics so that ecologists and managers can work in terms of ecological time. Quantitative assessment of trophic interactions is the fundamental part of this dynamics. The knowledge of ecosystem responses is crucial to support management decisions aimed at sustainable exploitation and diversity conservation.

\section{Acknowledgements}

This paper is part of a thesis by the first author submitted in partial fulfilment of the requirements for a Ph.D. Degree at the Instituto Oceanográfico, University of São Paulo, which was partially supported by Capes and CNPq. Financial support from CIRM (Comissão Interministerial para os Recursos do Mar) is gratefully acknowledged. We are especially appreciative of the review given to this paper by Dr. Janet W. Reid.

\section{References}

Ahlstrom, E.H., Thrailkill, J.R., 1963. Plankton volume loss with time of preservation. Calif. Cop. Oceanic Fish. Invest. Rep. 9, 57-73.

Alldredge, A.L., 1984. The quantitative significance of gelatinous zooplankton. In: Fasham, M.J.R. (Ed.), Flows of Energy and Materials in Marine Ecosystem: Theory and Practice. Plenum Press, New York, pp. 407-433. 
Andersen, V., 1985. Filtration and ingestion rates of Salpa fusiformis Cuvier (Tunicata: Thaliacea): effects of size, individual weight and algal concentration. J. Exp. Mar. Biol. Ecol. 87, 13-29.

Baird, D., Milne, H., 1981. Energy flow in the Ythan estuary, Aberdeenshire, Scotland, Estuar. Coast. Shelf Sci. 13, 455-472.

Banse, K., Mosher, S., 1980. Adult body mass and animal production/biomass relationships of field populations. Ecol. Monogr. 50, 355-379.

Biggs, D.C., 1977. Respiration and ammonium excretion by open ocean gelatinous zooplankton. Limnol. Oceanogr. 22, 108-117.

Brawn, V.M., Peer, D.L., Bentley, R.J., 1968. Caloric content of the standing crop of benthic and epibenthic invertebrates of St. Margaret's Bay, Nova Scotia. J. Fish. Res. Bd Can. 25, 1803-1811.

Brey, T., 1999. A collection of empirical relations for use in ecological modeling. Naga 22 (3), 24-28.

Brey, T., Jarre-Teichmann, A., Borlich, O., 1996. Artificial neural network versus multiple linear regression: predicting $\mathrm{P} / \mathrm{B}$ ratios from empirical data. Mar. Ecol. 140, 251-256.

Brown, P.C., Painting, S., Cochrane, K.L., 1991. Estimates of phytoplankton and bacterial biomass and production in the northern and southern Benguela ecosystems. S. Afr. J. Mar. Sci. 11, 537-564.

Buchanan, J.B., Warwick, R.M., 1974. An estimate of benthic macrofaunal production in the offshore mud of the Northumberland coast. J. Mar. Biol. Ass. UK 54, 197-222.

Castro-Filho de, B.M., Miranda de, L.B., Miyao, S.Y., 1987. Condições hidrográficas na plataforma continental ao largo de Ubatuba: variações sazonais e em média escala. Bolm Inst. Oceanogr., S Paulo 35, 135-151.

Christensen, V., Pauly, D. (Eds.), 1993. Trophic models of aquatic ecosystems. ICLARM Conf. Proc. 26, 390 pp.

Cole, J.J., Findlay, S., Pace, M.L., 1988. Bacterial production in fresh and saltwater ecosystems: a cross-system overview. Mar. Ecol. Prog. Ser. 43, $1-10$.

Deibel, D., 1982. Laboratory measured grazing and ingestion rates of salp Thalia democratica Forskal, and the doliolid Dolioletta gegenbauri Uljanin (Tunicata, Thaliacea). J. Plankton Res. 4, 189-201.

Deibel, D., 1985. Blooms of the pelagic tunicate, Dolioletta gegenbauri: are they associated with Gulf stream frontal eddies? J. Mar. Res. 43, 211236 .

Fenchel, T., 1974. Intrinsic rate of natural increase: the relationship with body size. Oecologia 14, 317-326.

Harbison, G.R., Gilmer, R.W., 1976. The feeding rates of the pelagic tunicate Pegea confederata and two other salps. Limnol. Oceanogr. 21, 517-528.

Heron, A.C., 1972. Population ecology of a colonizing species: the pelagic tunicate Thalia democratica. I. Individual growth rate and generation time. Oecologia 10, 269-293.

Humphreys, W.F., 1979. Production and respiration in animal populations. J. Animal Ecol. 48, 427-453

Ikeda, T., 1970. Relationship between respiration rate and body size in marine plankton animals as a function of the temperature of habitat. Bull. Fac. Fish. Hokkaido Univ. 21, 91-112.

Kalejta, B., Hockey, P.A.R., 1991. Distribution, abundance and productivity of benthic invertebrates at the Berg River estuary, South Africa. Estuar. Coast. Shelf Sci. 33, 175-191.

Koga, F., 1986. The occurrence and production of zooplankton in Suo-nada, western Seto Inland Sea. Bull. Nansei reg. Fish. Res. Lab. 20, 91-113.

Le Borgne, R., 1982. Zooplankton production in the eastern tropical Atlantic Ocean: net growth efficiency and P:B in terms of carbon, nitrogen and phosphorus. Limnol. Oceanogr. 27, 681-698.

Linley, E.A.S., Newell, R.C., Bosma, S.A., 1981. Heterotrophic utilisation of mucilage released during fragmentation of kelp (Ecklonia maxima and Laminaria pallida). I. Development of microbial communities associated with the degradation of kelp mucilage. Mar. Ecol. Progr. Ser. 4, 31-41.

Longhurst, A.R., Pauly, D., 1987. Ecology of Tropical Oceans. Academic Press, San Diego 407 pp.
Longhurst, A.R., Sathyendranath, S., Platt, T., Caverhill, C., 1995. An estimate of global primary production in the ocean from satellite radiometer data. J. Plankton Res. 17, 1245-1271.

Mahiques, M.M., 1995. Dinâmica sedimentar atual nas enseadas da região de Ubatuba, estado de São Paulo. Bolm Inst. Oceanogr., S Paulo 43, 111-122.

McNeill, S., Lawton, J.H., 1970. Annual production and respiration in animal populations. Nature 225, 472-474.

Ménard, F., Dallot, S., Thomas, G., Braconnot, J.C., 1994. Temporal fluctuations of two Mediterranean salp populations from 1967 to 1990. Analysis of the influence of environmental variables using a Markov chain model. Mar. Ecol. Prog. Ser. 104, 139-152.

Mendo, J., Bohle-Carbonell, M., Calienes, R., 1989. Time series of upwelling nitrate and primary production off Peru derived from wind and ancillary data, 1953-1982. ICLARM Conf. Proc. 18, 64-76.

Metzler, P.M., Gilbert, P.M., Gaeta, S.A., Ludlam, J.M., 1997. New and regenerated production in the South Atlantic off Brazil. Deep-Sea Res. Part I (44), 363-384.

Michaels, A.F., Silver, M.W., 1988. Primary production, sinking fluxes and the microbial food web. Deep-Sea Res. 35, 473-490.

Odebrecht, C., Garcia, V.M.T., 1997. Phytoplankton. In: Seeliger, U., Odebrecht, C., Castello, J.P. (Eds.), Subtropical Convergence Environments. The Coast and Sea in the Southwestern Atlantic. Springer-Verlag, Berlin, pp. 105-109.

Opitz, S., 1991. Quantitative models of trophic interactions in Caribbean coral reefs. Ph.D. Thesis. Fakultat der Christian-Albrechts-Universitat. Kiel, Germany 470 pp.

Paffenhöfer, G.A., Lee, T.N., 1987. Development and persistence of patches of Thaliacea. S. Afr. J. Mar. Sci. 5, 305-318.

Pires-Vanin, A.M.S. (Ed.), 1993. Estrutura e função do ecossistema de plataforma continental do Atlântico brasileiro, 10. Publção esp. Inst. Oceanogr., S Paulo 145 pp.

Riley, G.A., Gorgy, S., 1948. Quantitative studies of summer plankton populations of the western North Atlantic. J. Mar. Res. 7, 100-121.

Rocha, G.R.A., Rossi-Wongtschowski, C.L.D.B., Soares, L.S.H., JarreTeichmann, A., 2003. Seasonal budgets of organic matter in the Ubatuba shelf system, south-eastern Brazil. II. Fish components. Oceanol. Acta in press (this issue).

Shushkina, E.A., Vinogradov, M.Ye, Sorokin, Yu.I., Lebedeva, L.P., Mikheyev, V.N., 1978. Functional characteristics of planktonic communities in the Peruvian upwelling region. Oceanology 18, 579-589.

Smetacek, V., 1984. The supply of food to the benthos. In: Fasham, M.J.R. (Ed.), Flows of Energy and Materials in Marine Ecosystems: Theory and Practice. Plenum Press, New York, pp. 517-547.

Thayer, G.W., Schaaf, W.E., Angelovic, J.W., La Croix, M.W., 1973. Caloric measurements of some estuarine organisms. Fish. Bull. U.S. 71 (2), 289-296.

Tranter, D.J., 1960. A method for determining zooplankton volumes. J. Cons. Int. Explor. Mer. 25, 272-278.

Uye, S.-I., Kuwata, H., Endo, T., 1987. Standing stocks and production rates of phytoplankton and planktonic copepods in the Inland Sea of Japan. J. Oceanogr. Soc. Japan 42, 421-434.

Valiela, I., 1995. Marine Ecological Processes. Springer-Verlag, New York $686 \mathrm{pp}$.

Vinogradov, M.Ye, Shushkina, E.A., Kukina, I.N., 1976. Functional characteristics of a planktonic community in an equatorial upwelling region. Oceanology 16, 67-76.

Warwick, R.M., George, C.L., Davies, J.R., 1978. Annual macrofauna production in a Venus community. Estuar. Coast. Mar. Sci. 7, 215-241.

Wulff, F.V., Ulanowicz, R.E., 1989. A comparative anatomy of the Baltic Sea and Chesapeake Bay ecosystems. In: Wulff, F.V., Field, J.G., Mann, K.H. (Eds.), Network Analysis in Marine Ecology - Methods and Applications. Coastal and Estuarine Studies, vol. 32. SpringerVerlag, New York, pp. 232-256. 